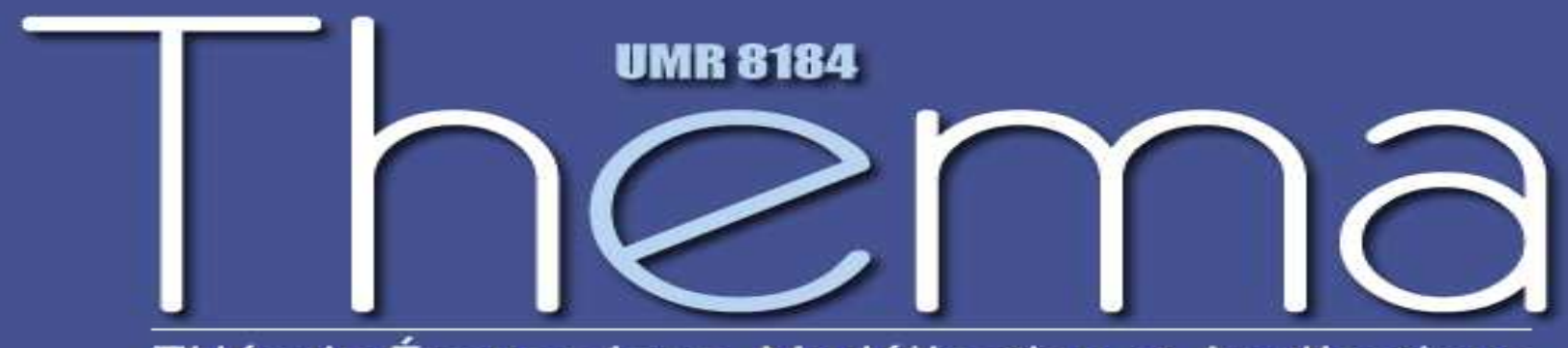

THéorie Économique, Modélisation et Applications

THEMA Working Paper n²017-19 Université de Cergy-Pontoise, France

The Contestable Marketplace of Ideas: Paul Samuelson's Defense of Mainstream Economics through Textbook Making, 1967-1976

Yann Giraud 


\title{
The Contestable Marketplace of Ideas: Paul Samuelson's Defense of Mainstream Economics through Textbook Making, 1967-1976
}

\author{
Yann Giraud*
}

Draft 2.0 (February 2017), not for quotation

\begin{abstract}
Historians of economics rarely consider textbooks as more than passive receptacles of previously validated knowledge. Therefore, their active role in shaping the discipline and its image is seldom addressed. In this paper, I study the making of Paul Samuelson's successive editions of Economics from 1967 to 1976 as an instance of how textbooks stand at the crossroads between disciplinary knowledge, pedagogy and larger political and societal concerns. In the mid-1960s, Economics, now at its sixth edition, was at the height of its success. Considered one cornerstone of modern economics, it was also the center of a number of criticisms dealing with the current state of the economic discipline and its teaching in the universities. While the profession expressed its concern over the lack of relevance of economics to address the pressing issues of the day and pleaded for a new "problem-solving" approach to economic education, the late 1960s witnessed the emergence of a new generation of "radical" economists criticizing the economics orthodoxy. Their contention that mainstream theory had neglected the issues of class struggle and capitalist exploitation, found a favorable echo among an increasingly politicized population. Using archival materials, I show how Samuelson, helped by his editorial team at McGraw-Hill, attempted to take into account these changes in order to ensure the continuing success of subsequent editions of his text in an increasingly competitive market. While this study emphasizes Samuelson's ambiguous attitude toward his contenders, revealing on the one hand his belief in a free marketplace of ideas and, on the other hand, his attachment to mildly liberal politics and aversion to Marxism, unchanged through revisions, it also shows that the textbook is a collective endeavor, embodying different stakeholders' views and market forces. Therefore, those who are interested in studying textbooks as a way to retrace the development of economic knowledge should not necessarily postulate authorial intent.
\end{abstract}

Keywords: Paul Samuelson, economics textbooks, economic education, radical economics

JEL codes: A14, B20, B3

\footnotetext{
Correspondence may be addressed to Yann Giraud, ThEMA, Université de Cergy-Pontoise, 33 Boulevard du Port, 95011 Cergy-Pontoise cedex, France (yann.giraud@u-cergy.fr). In the course of this research, I have benefitted from the material help of the David M. Rubenstein Rare Book and Manuscript Library at Duke University and from funding provided by the History of Recent Economics European Scientific Coordination Network (GDRE CNRS 711) at the École Normale Supérieure de Cachan. I am thankful to Roger Backhouse, Jean-Baptiste Fleury, Kevin Hoover and Steve Medema for their comments on an earlier draft of this paper and to Béatrice Cherrier for providing me with a few additional archival materials from MIT. The usual caveat applies.
} 


\section{The Contestable Marketplace of Ideas: Paul Samuelson's Defense of Mainstream Economics through Textbook Making, 1967-1976}

\section{Introduction}

In the beginning of the year 1975, MIT economist Paul Samuelson (1915-2009) briefly contemplated the idea of ceasing to be the author of Economics. ${ }^{1}$ The best-selling introductory text, which he had started to draft thirty years earlier, was now at its $9^{\text {th }}$ edition and in need of the usual every-three-years update. Samuelson, though, was unwilling to carry on with yet another round of revisions of the 900-page doorstop and, instead, he envisioned his retirement from the textbook writing business altogether. To McGraw-Hill's Publisher Howard Aksen, he wrote:

Now that I am about to turn sixty, my physician and I have taken a close and realistic look at my schedule. For years, I have been trying to crowd into it more than one person's quota of activities, and we are both agreed that the arrival of one's seventh decade of life is an appropriate time to remedy this situation. ${ }^{2}$

Although an arrangement was soon reached to ensure the pursuance of the enterprise, Samuelson's momentary fatigue is telling. Textbooks may be considered by practicing economists and historians of the discipline alike as less important in the development of knowledge than journal articles or extended essays, yet in one's academic life they can

\footnotetext{
${ }^{1}$ The textbook's full title was Economics: an Introductory Analysis when it was first published in 1948, before it was shortened to Economics from the eighth edition (1970) onwards. In the following we will use Economics for all the editions, as is customary.

${ }^{2}$ Samuelson to Howard Aksen, March 14, 1975, Paul A. Samuelson papers (hereafter cited as PASP), David M. Rubenstein Rare Book \& Manuscript Library, Duke University, Box 83, Folder “ $10^{\text {th }}$ edition: draft, corrections".
} 
represent an exhausting sum of efforts. Why would a renowned theorist - not to mention a recent Nobel Memorial Prize recipient - such as Samuelson accept to trade some precious research time in exchange for the hassles that writing and revising an introductory text brings? The answer, of course, is that textbooks play a far greater role than is usually acknowledged. Historian of science Marga Vicedo (2012) has made this claim by criticizing the received view that textbooks are only "passive receptacles" of past knowledge and by pointing to the many different ways in which they have participated in scientific developments. A nonexhaustive list includes: defining what good science is and explaining how it should be pursued; accompanying the development of new subfields of research; raising epistemological and larger societal concerns about knowledge; and attributing credit for scientific discoveries. ${ }^{3}$ This observation is valid for any discipline at various points in its development but it holds especially true for a field where knowledge is evolving rapidly and still wildly contested. Postwar economics, therefore, offers a very good occasion to study textbooks as active agents in the development of a field. While several contributions to the history of economics have attempted to trace the development of economic knowledge in the postwar period through different editions of Economics, only a handful have tried so far to understand how the textbook itself developed and all of them focused mostly on the making of the first edition (1948). ${ }^{4}$

\footnotetext{
${ }^{3}$ For illustrations of how textbooks have helped shape scientific knowledge, see Kaiser 2005 (chapter 7) on postwar physics and Rocke 2010 (chapter 4) on nineteenth century chemistry.

${ }^{4}$ These accounts have often been critical of Samuelson's textbook, trying to emphasize his bias towards some ideological or methodological commitments. See for instance Skousen 1997, Nelson 2001 and Levy and Peart 2009. Other accounts such as Samuelson 1997 and Gottesman, Ramrattan and Szenberg 2005 offer apologetic perspectives on the textbook. Other uses of Economics, along with other textbooks, to trace the development of economics concepts can be found in Medema 2014 and Forder 2015. For an account of the early development of the textbook, see Giraud 2014 and Backhouse 2017 (chapters 25, 26 and 27).
} 
This paper, accordingly, offers an account of the way Economics was revised between 1967 and the 1976. The years under scrutiny are relevant because they correspond to a period when "mainstream" economics had come to maturity as a relatively coherent whole - what Mary Morgan and Malcolm Rutherford (1997) characterized "postwar neoclassicism" - yet began to be strongly criticized by dissenters. ${ }^{5}$ Samuelson, who had been depicted in the New York Times as the "leader of economic mainstream", whose "views, once radical," had "become establishment economics" (Reinhold 1970, 8), was the target of choice for these critics. His 'middle-of-the-road' version of economics, which earlier editions of the textbook had helped spread, was so ubiquitous that scholars and students interested in a more radical critique of the capitalist system would necessarily have to take him to task. ${ }^{6}$ More specifically, our paper portrays the way the author, helped by his editorial team at McGrawHill, reacted to these attacks, as well as to the larger issues affecting economic education, at a time when the latter was seen by most practitioners as experiencing a crisis of relevance. Samuelson tried to show through successive revisions of his text that the branch of

\footnotetext{
${ }^{5}$ Past contributions have tried to define "mainstream" more precisely, for instance Colander, Holt and Rosser Jr. 2004, Davis 2006 and De Vroey and Pensieroso 2016. These contributions emphasize that mainstream and neoclassical economics are two different entities. In contrast to the more doctrinal "neoclassical", "mainstream" is depicted as pluralistic as it encompasses schools of thoughts and subfields of economics that were initially critical of neoclassical tenets. Our paper, however, does not adopt a precise definition, as the actors in our story use the word in ways that are themselves quite ambiguous. This will be seen in section 4, when Samuelson ends up using the term in the $9^{\text {th }}$ edition. At this point, suffice to say that "mainstream economics" is more often defined by its critics, as "what established economists do".

${ }^{6}$ The term 'middle-of-the-road' has been used many times by Samuelson himself both in private correspondence and in publication - for instance, "I prefer to stick to middle-road of good, strong value" ("Money, Interest Rates and Economic Activity: Their Interrelationship in a Market Economy" in Merton 1972, p. 569). Its meaning, however, is ambiguous. While it is often equated with Samuelson's 'neoclassical synthesis', a term which was coined by Samuelson in the $3^{\text {rd }}$ edition of Economics to designate a mix between Keynesian macroeconomics and neoclassical microeconomics, it can also be understood as a policy-oriented view, standing midway between laissez-faire and state planning. At the meta-level, "middle-of-the-road" embodies Samuelson's general attitude towards economic expertise as a reasonable response to ideological extremes. See Giraud 2014 on how this attitude developed in reaction to conservative criticisms of the first edition of the textbook.
} 
mainstream economics he was promoting could still be apolitical while simultaneously able to tackle the social issues of the day - including those that dissenting economists were addressing. For his opponents, on the contrary, mainstream economics was necessarily tied to bourgeois ideological values and therefore too conservative to tackle those issues satisfyingly. In addition, there was another important line of division between Samuelson and his critics: while the MIT Professor was willing to rely upon the tools offered by the textbook market in order to enforce his vision, believing that there was such thing as a free market of ideas, dissenting economists criticized not only the substance of Economics but, more largely, the growing commercialization of economic education that the textbook exemplified.

Section 2 studies the context in which the revision of Economics became especially crucial, depicting the crisis in economic education and the increasing competition on the textbook market Samuelson had to take into account as he worked on the $7^{\text {th }}$ edition (1967) of his textbook. Section 3 deals with the appearance of the radical critique of mainstream economics, which occurred as Samuelson was preparing the $8^{\text {th }}$ edition of his text (1970). This radical critique was particularly relevant to the textbook because it first developed at the educational level. I show that Samuelson's attitude towards this new movement was quite ambiguous, being neither totally hostile nor amicable. The author did not address it but tried instead to so by approaching larger societal issues in the textbook. Section 4 depicts Samuelson's increasing efforts to take into account the radicals' point of view when revising his textbook for its $9^{\text {th }}$ edition (1973). While these revisions were inefficient in convincing his critics, leading to more criticism on their part, they helped cement a cohesive version of mainstream economics. Section 5 will offer concluding remarks, reflecting on the increasing commercialization of economics textbooks and the subsequent "death" of the textbook author. 


\section{Samuelson's Economics in the mid-1960s and the crisis of relevance}

It is hardly debatable that in 1967 Paul Samuelson's Economics was still the most influential economics textbook in the United States. Not only had it been a clear success from the very beginning - selling more than 100,000 copies of its first 1948 edition - and was quickly adopted in major US institutions of higher education - but its sales figures had also never ceased to increase with each new edition up to this point. ${ }^{7}$ In addition, the way it taught introductory economics - separating macroeconomic and microeconomic concepts and tools, giving depiction of the US economy and devoting attention to issues of competing economic systems - had become the commonly accepted practice in the classroom and provided the blueprint for a number of competing textbooks.

However, new developments in economic education in the United States increasingly contributed to challenge the preeminence of Samuelson's text. The early 1960s had witnessed growing skepticism among practitioners over the state of economic education in colleges and high schools. Many economists expressed their dissatisfaction with the teaching of the introductory course, which they believed was insufficient in drawing students' interest. A 1958 conference at Grinnell College, co-sponsored by the Ford Foundation and the Joint Council on Economic Education, studied alternative approaches to economic education, other than the usual "principles-based" course. These studies, published in 1960, showed that most of the participating teachers believed in the superiority of the "problems-solving" approach. Unlike "principles-based" economics courses, which introduced theories to students before applying them to various problems, "problem-solving" courses worked in reverse, exposing the issues that the American society had to face before exposing the economic principles one

\footnotetext{
${ }^{7}$ Elzinga (1992) shows that 1967 represented a peak in Economics' sales, with 182,422 copies sold. From there, sales began to decrease though the textbook remained highly successful until the early 1980 s.
} 
could use to solve them. ${ }^{8}$ Paradoxically, Samuelson's Economics, which was considered in 1948 as one of the first textbooks to confront students with the pressing issues of the day, was a decade later classified among the most theoretically loaded texts and accordingly challenged by more policy-oriented contenders. Among the most successful textbooks to adopt the "problem-solving" approach was George Leland Bach's Economics: An Introduction to Analysis and Policy (first edition in 1954). Its author, then the dean of the Carnegie-Mellon business school, was also much involved in the development of economic education, a field which had been vigorously supported by the American Economic Association since the beginning of the decade. In 1964, together with fellow economic educationist Philips Saunders, Bach undertook a quantitative study of the impact of introductory courses on economic literacy, showing that such courses had no significant effect on success in a simple test of economic understanding submitted to a sample of high school social teachers (Bach \& Saunders 1965). The outcome of their study was a subsequent refinement of the test with slightly better results (Bach and Saunders 1970), but for the most, economic education was considered a quite depressing affair in the 1960s and the classic economics textbook - as represented by Economics and its numerous imitators - was often held responsible for the present situation.

Despite these criticisms, Economics was judged as superior to its competitors due to its relative seniority and to the fact it benefitted from the numerous revisions that had been undertaken over the past decade. ${ }^{9}$ Its main competitor in the period was McConnell's

\footnotetext{
${ }^{8}$ On the birth of the 'problem-solving' textbook and its legacy in economic education, see Fleury (2012).

${ }^{9}$ This is how Samuelson's text was characterized in a detailed study of the textbook market written in 1965 for the New York State Council on Economic Education. The study was also used by McGraw-Hill as a way to survey competing texts and addressed to Samuelson to help him with his revisions for the $7^{\text {th }}$ edition. "A Guide to the Selection of College Economics Textbook" by Laurence E. Leamer, September, 1965, PASP, Box 81, Folder " $7^{\text {th }}$ edition correspondence 1 of 3 ".
} 
Economics (first published in 1960 as Elementary Economics: Principles, Problems, and Policies), which was also a McGraw-Hill product. McConnell was considered a more policyoriented introductory text, addressing American agricultural issues and economic equalities through the prism of Kenneth Galbraith's recently published Affluent Society. Yet these differences were more in general outlook than in actual content, so that an outsider could have seen McConnell's text as a relatively less technical version of Samuelson's. One can wonder why the publisher would want to keep similar textbooks in its selection but the most plausible answer is basic: because texts were only revised every three years, there needed to be at least one McGraw-Hill textbook to fill the gap when some institutions had to opt for a newer, fresher book with updated data. As a result, the two textbooks were clearly leading the market in the 1960s, leaving limited space for other competitors. Yet a strong feeling of competition between the two books was constantly maintained at McGraw-Hill.

On the other hand, Economics' main drawback on the current market was the fact that it did not adopt a clear-cut approach but instead stood in-between different styles of textbooks. While it was too principle-oriented and too technical for the students looking for a simple introduction to economic issues - for this purpose, Bach's or McConnell's texts would do a better job -, it was also surpassed by the arrival of more technical textbooks such as Richard Lipsey and Peter Steiner's Economics (first edition in 1966). An American version of Lipsey's British best seller An Introduction to Positive Economics (1963), it was described by Sidney Josephs, McGraw-Hill editor in England, as a serious contender to Economics, a "breakthrough" book which had already "replaced Samuelson wherever the emphasis is on the mathematical approach to economics" and could be soon adopted by most institutions as 
the field becomes more mathematical. ${ }^{10}$ Despite the difference between American and British economic education, Samuelson's editors feared that a new textbook written by an author recognized as a talented young researcher could quickly establish itself as the new standard, pretty much in the same way Samuelson's text had done so back in 1948. Lipsey had indeed conceived his text out of his dissatisfaction with Economics, which he though was insufficient on the microeconomic side. ${ }^{11}$ Lipsey's plea for a more scientific, "positive" economics, along with some applications to the US economy provided by Peter Steiner, was likely to attract a number of instructors and students who were repelled by Samuelson's chattier style. ${ }^{12}$ To cope with the growing competition, an evolution of the text should be undertaken.

Of course, Samuelson was not alone in performing this task. At McGraw-Hill, he was helped in this process by an experienced team of editors, assistants, publicists and travelers, surveying the textbook market on a regular basis, providing newspapers, professional magazines and institutions with the latest information and blurbs on the textbook and collecting various field reports. Particularly useful were the travelers who, as sales representatives, reported on the textbook demand in their local institutions and passed on to the editors the various reports that instructors wrote in response to the latest edition. While some of these were unsolicited comments and suggestions - including some minor corrections

\footnotetext{
${ }^{10}$ Sydney Josephs (UK Senior editor at McGraw-Hill) to Bruce Keezer (US college division editor), December $9^{\text {th }}, 1965$, PASP, Box 81 , Folder " $7^{\text {th }}$ edition, Correspondence 1 of 3 ".

${ }^{11}$ See Lipsey 1997, p. x. Lipsey was later dissatisfied with the American version of his textbook, on which he wrote: "It soon became clear... that IPE was too austere and too sophisticated for the typical first-year undergraduate... This slowly gave way under enormous US market pressure to teach theory as something closer to revealed truth, particularly in micro. It was a painful process and, although a good but more orthodox book emerged, I felt at every stage that I was taking part in the dismemberment of my own baby (ibid, p. xv)."

12 Samuelson later said of its "chatty style" that it was a conscious decision. To fellow McGraw-Hill mathematics textbook writer Ralph Agnew, he wrote: "In 1948, I deliberately tried to write a colloquial prose... On the whole the popular tone of the book, which contrasted with its implicit rigor, was probably commercially advantageous”. Samuelson to Agnew, May 16, 1961, PASP, Box 79, Folder “Economics 1946-2008, 2 of 2”.
} 
-, there were also formal reports, which were used by McGraw-Hill in preparing the revision. These documents contained general comments as well as chapter-by-chapter detailed analysis. The comments concerned the technical aspects of the book as well as its tone and the various political recommendations it contained. Less frequently, they were accompanied by quite unflattering students' comments that ranged from "like dry toast" to "a little senile but interesting" or complained about the presence of "a lot of propaganda talk." What stood out from these various comments was that the book was too long and too detailed for a one or two-semester course. Whereas, in the preceding decade, Samuelson was criticized for not taking into account the variety of economic thinking, the general opinion was that it failed to cut through the various existing theories. Apparently, this was especially the case with the microeconomic section - which was reduced to a minimum in the first edition -, leading one instructor to write: "The book makes too much of an effort to mention all, or at least the great majority, of the various economic theories which bear on various points." ${ }^{\text {"13 }}$ Many readers, students and instructors alike, felt that there was a need for a shorter version of Economics, devoted to some particular branch of the audience, and the idea of splitting the text into a twovolume - micro and macro - book was discussed. What probably refrained Samuelson and his team from doing so was the fact that the synthesis between macro and micro was also seen as the book's main advantage in regards to competing text. ${ }^{14}$

Another important concern was to make Economics appear as relevant on the policyside. In fact, these policy-oriented aspects were the main points that the editors put forth when

\footnotetext{
${ }^{13}$ Gerald C. Spencer (McGraw-Hill editor) to Paul Samuelson, October 10, 1968, PASP, Box 81, Folder "Reviews of Text".

${ }^{14}$ Interestingly, as Pearce and Hoover (1995) have noted, Samuelson downplayed the "neoclassical synthesis" in the $7^{\text {th }}$ edition, calling it instead "new economics". This change may have been related to the fact that Samuelson's macroeconomics was increasingly contested by competing views such as Friedman's monetarism and that he wished to promote his model as being more general. "Neoclassical synthesis" was therefore removed from the index in subsequent editions.
} 
promoting the book. In this setting, the teaching of economic principles did not appear as an end in itself but as a means to understand the news and to provide sound policy advices. The press release accompanying the publishing of the 7th edition in 1967 focuses almost exclusively on these elements, confronting some passages of the textbook with recent newspapers headlines (see fig. 1 below). This was also reflected in the revised introduction, in which appeared for the first time a diagram showing different projections of US and USSR growth rates between 1960 and 2000, illustrating the necessity of combining "scientific analysis" and "the art of judgment" to break free from "wishful or paranoid thinking" (Samuelson, 1967, p. 3). McGraw-Hill wished to promote Samuelson as a policy expert rather than as a theoretician, building on his recent association with Newsweek, where he had begun writing columns the year before.

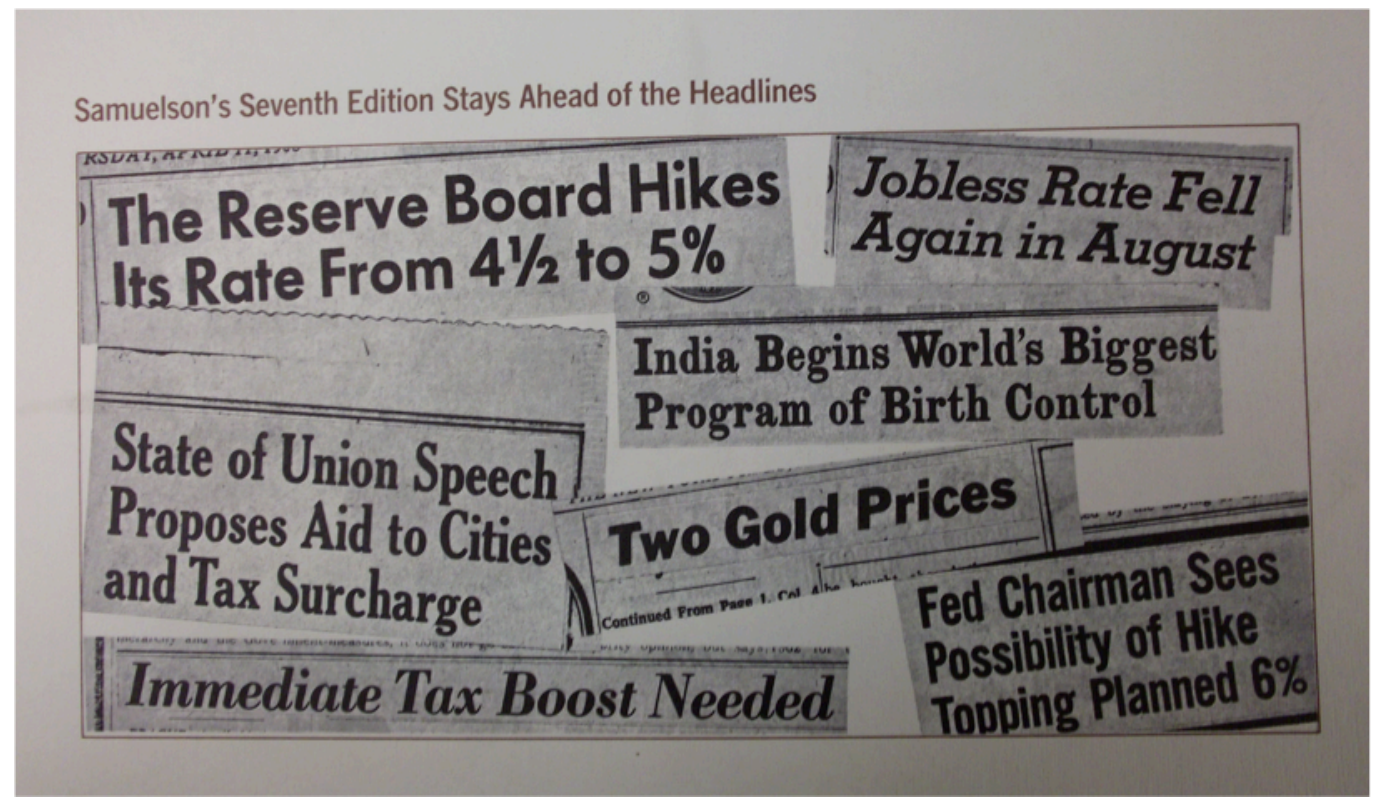

Figure 1. Source: PASP, Box 80, Folder "Promotion 2 of 3"

However, it is doubtable that Samuelson's version of political debates was what mainly interested young readers in the mid to late 1960s. The policy content in Economics focused on comparative systems and macroeconomic issues, such as the inflation/employment 
debates between neo-Keynesians and Friedmanites. The $7^{\text {th }}$ edition addressed contemporary issues, for instance the Vietnam War, but what was studied was the consequence of the conflict in terms of inflation and public expenditures, not its more political aspects such as economic imperialism and competing ideologies increasingly denounced on American campuses. Inequalities, race and gender discrimination as well as environmental issues were not treated frontally. This may explain why the $7^{\text {th }}$ edition was considered by Samuelson, as well as by his Editors, as some kind of disappointment. Though it had sold more copies than any previous edition in its first year, it was also the first edition to sell fewer copies over its three-year run than the previous one. ${ }^{15}$ In this increasingly challenging context for Samuelson's textbook, the appearance of radical criticisms of mainstream economics would bring further challenges to Samuelson and lead to more revisions.

\section{The rise of radical economics and its impact on Samuelson's $8^{\text {th }}$ edition}

Though the rise of radical economics in the late 1960s is often associated with a few names like Samuel Bowles, Herbert Gintis or Michael Zweig, and equated with the rebirth of Marxist thought in the field, it was in the beginning a larger emanation of several dissenting movements that encompassed racial, gender and environmental issues, without a unified identity. ${ }^{16}$ To make it clear, when these movements appeared in 1967, the issues they thought as being the most important were exactly those that the latest edition of Samuelson's textbook failed to address. In addition, the radicals' critique of establishment economics came from

\footnotetext{
${ }^{15}$ In addition, Samuelson had been very critical of the way his revisions for the $7^{\text {th }}$ edition had been handled by his editors at McGraw-Hill and had written to Edward Booher, the publisher's President, to voice his discontent, asserting implicitly that McConnell had benefitted from a more favorable treatment (Samuelson to Booher, March 21, 1967, PASP, Box 81, Folder “ $7^{\text {th }}$ edition Correspondence 2 of 3"). Subsequently, he worked on the next couples of revisions with a new editor.

${ }^{16}$ On the construction of the identity of radical economists and their subsequent migration to specific economic departments, see Mata (2009).
} 
graduate students and young researchers who were deeply engaged in teaching and believed that the revolution should begin in the classroom. For this reason, they criticized not only the theories and the tools used in standard economics, but also the way those were taught at the University. In addition, textbooks were easy targets because they incorporated a mix of technical and verbal economics that made the underlying ideological premises of the theory more obvious to the reader. Samuelson's defense of the mixed economy were not hidden between matrices and systems of equations but were offered quite openly to the critics. To textbook authors like Samuelson, radical economists were threatening, not so much because of their advocacy of a new framework in economic research, but because their criticisms reinforced the crisis of relevance that economic education was facing at the time. Their response should consist in convincing their readers that the basic economic principles found in their introductory texts could be helpful to treat the most pressing issues of the day.

As Tiago Mata (2009) has shown, radical economics began not in peripheral institutions but within institutions that were central in the development and teaching of mainstream economics: Harvard, MIT and the University of Michigan. Though the Union for Radical Political Economy (URPE) had been created at the Ann Harbor campus, Harvard was where the activities of radical economists were the most publicized. There, a radical economics course was taught by Arthur MacEwan, Samuel Bowles, Herbert Gintis and Thomas Weisskopf, who were all either young Assistant Professors or PhD students. Their enterprise gained more publicity in April 1969 when these academics, along with their students, participated in the occupation of the administration building, protesting against the extension of the Harvard campus. The quite brutal handling of the situation by the authorities was controversial among Harvard scholars and drew a lot of press coverage. For this reason, radical economics became a widespread subject inside and outside academia. 
Samuelson's MIT was also concerned by the radical movement. In November 1969, URPE organized there an important meeting whose aim was to initiate reflection on the establishment an alternative paradigm in economics. Marxist economist Paul Sweezy, an old acquaintance of Samuelson when the latter was a graduate student at Harvard, was one of the main speakers. On November 17, 1969, Samuelson spoke about the radical critique at a symposium organized by the American Bankers Association. He was accompanied by Harverford College President, John R. Coleman, a former colleague of his at the MIT economics department and one of the co-editors of his Readings in Economics volume. Coleman took a clear defense of the radical movement, asserting that students were pointing at issues of morality that, he argued, businessmen ought to take into account. In his talk, reported in an article from the Washington Post, he also criticized economic growth for its own sake and pleaded for a more equitable income distribution, "especially for blacks". Samuelson's comments were more critical of the radicals. "The over-riding problem of economics today", he wrote, "is that some of the best young minds will simply have tuned out from the study of conventional economics entirely." He estimated that the radical economics course at Harvard was selected by the students only to confirm "opinions already held" (Rowen 1969). Samuelson's critical comments, as reported in the newspaper, drew criticism from Samuel Bowles, who wrote to him: "Thanks for drumming up publicity for radical economics. I didn't much like the way you characterized our course (and its students) in your talk reported in the POST. Our students are generally interested in a different range of issues than that covered in Ec 1 but that can hardly be evidence of closed minds." ${ }^{117}$ After Samuelson sent him the full text of his talk, Bowles replied with a more detailed depiction of how social concerns should be addressed in the economics classroom:

\footnotetext{
${ }^{17}$ Bowles to Samuelson, undated correspondence (November-December 1969), PASP, Box 61, Folder "Radical economists".
} 
I have become increasingly skeptical that the kinds of tools which we teach in the basic graduate courses in theory, for example, are of much use in developing solutions to the kinds of problems which concern both of us. I am sure that you have been dealing with many of these problems in the process of revising your undergraduate text. What can you say about "the problem of poverty," the "dilemmas of urban blight and environmental pollution," about racism, about the military-industrial complex, and about the quality of life in a theoretical context, the main assumptions of which render technological change and personal preferences exogenous, and which continues to accept profit maximization as the main determinant of resources allocation in the private sector?... It seems to me that we need a paradigm for economics which makes externalities and the endogenous nature of tastes and technological change central to our attention rather than the unwanted nuisances normally relegated to prefaces and footnotes. In any case, I look forward to seeing your new text. ${ }^{18}$

Admittedly, a number of mainstream economists recognized that the radicals had a point when it came to educational matters. In his 1970 appraisal of radical economics, Martin Bronfenbrenner observed that "radical economic education is a topic in which standard economists have much to learn". Among its beneficial characteristics, he noted that "class discussion and outside readings" were "more important than in corresponding standard courses", that the reading lists he had seen were "no more biased than standard reading lists" and that the courses were "highly structured" and "on a higher intellectual level" than the standard ones. He praised the "participation in surveys and research" and the "prolonged visits to both the slums (urban or rural) and the swankier suburbs" (Bronfenbrenner 1970,

\footnotetext{
${ }^{18}$ Bowles to Samuelson, December 22, 1969, PASP, Box 61 Folder "Radical economics".
} 
757). Yet lauding the radicals' pedagogical schools was a two-edged remark as it also highlighted that they had little to offer on the research side. Among the most critical commenters, Robert Solow, Samuelson's colleague at MIT, wrote a virulent assessment of radical economics, noting that "as it is practiced" it "contains more cant, not less cant; more role-playing, not less role-playing; less facing of the facts, not more facing of the facts, than conventional economics" and concluding laconically "I don't think a survey of the current state of economics needs to pay a lot of attention to radical economics (Solow, Heilbroner and Riecken 1971, 63-5)." Samuelson did not voice such disparaging comments towards radical economists in print but his assessment of their research exuded skepticism. Asked to review a grant proposal by Bowles for the Carnegie Corporation in the field of education economics, he replied:

Sam Bowles is the "dean of radical economists." He is intelligent, well-trained and motivated. More surely of him than of any of his colleague can one predict that he will make a mark in academic life and economic research. If money cannot be found to support his research interests, a fortiori it will be difficult for many other radical economists to receive financial support for their research. And since economists of my generation are not slow to note that the glaring lack in connection with the movement toward a more radical economics is the almost total absence of any respectable research accomplishment, the radical young could be forgiven for developing some feeling of paranoia that the "interests" are out to suppress them.

On the research project itself, after expressing reservations over the novelty of a study showing that education aimed at reproducing material success in the American economy, he noted: "Some of the doubts that I might have concerning the new knowledge to be expected 
from this research is tempered by the consideration that in a great, pluralistic society, any group's research is part of a vast adversary process, out of which may emerge greater wisdom than is inherent in any one of its parts." 19

Accordingly, we may think that it is mostly for the sake of pluralism rather than by genuine openness to the radicals' ideas that Samuelson tried to address their criticisms in the $8^{\text {th }}$ edition of his textbook. In the preface, Samuelson presented this novelty, as well as a few other ones, as "a change in the spirit of the book" that tried to clear out "complacency and smugness". He mentioned three critics on "the New Economics" that his textbook would have to take into consideration: John Kenneth Galbraith and his views on "the new industrial state" as expressed in his 1967 book, the radical economists, who insisted "that every facet of our society be subjected to unsparing criticism" and libertarian economists, "like Milton Friedman of the University of Chicago" who were challenging "the consensus of post-Keynesian analysis". ${ }^{20}$ To these "cogent criticisms", Economics would offer "a dispassionate hearing" (Samuelson 1970, vi). In practice the most obvious changes were the inclusion of two new chapters in Part 6 of the textbook, devoted respectively to "Economic inequality: Poverty, Affluence, and the Quality of Life" (Chapter 39) and "Economic Problems of Race, Cities and the Polluted Environment" (Chapter 40). To treat these issues, however, Samuelson did not use the concepts and wordings of radical economic but relied instead on the discipline's standard tools. In the first of these two chapters, Samuelson dismissed the idea that growth only benefitted the richest, providing graphical evidence that "all classes have shared in century's progress" (Samuelson 1970, 765). On the accompanying diagram (fig. 2 below), the

\footnotetext{
${ }^{19}$ Samuelson to E. Alden Dunham (Carnegie Corporation), May $8^{\text {th }}$, 1970, PASP, Box 61, Folder "Radical economists".

${ }^{20}$ It should be noted that Galbraith had been an ardent defender of radical economics and was often categorized within the radical group.
} 
fact that the revenue of the lower half had reached $A$ ' following Pareto's law showed that "the cruder forms of Marxism" had been wrong in predicting that poor would reach "complete immiserization", shown at point $Z$ on fig. 2 below. Still, the fact that the curve had not reached point E proved that the system was still far from perfect egalitarianism. In defense of the middle-of-the-road position against "[c]ritics of the system" on the one hand and "[d]isplaced conservatives" on the other hand, he advanced the fact that "Ford workers get real wages ten times what their great-grandfathers got because their productivity in Detroit enables that wage to be paid" and asserted that "[e]ven in the eastern academies of Eastern Europe it is now agreed that the mixed economies of Western Europe and North America are likely in 1999 to have real wages several times those prevailing in the 1970s" (ibid, 766). Further in the chapter, he also criticized Galbraith's prediction that the end of scarcity would happen at mid-century, and rather quoted extensively from Keynes' "Economic Possibilities for Our Grandchildren" (ibid, 776-7). The second new chapter was mostly devoted to racial discrimination, using supply and demand curves to show that racial discrimination led to lower wages for black people and a lower total output of product (ibid, 791) and that urban discrimination would also lead to a situation in which "landlords as a class actually lose" (ibid, 791). In the next chapter, pollution was devoted little space, being treated quite traditionally as an externality. 


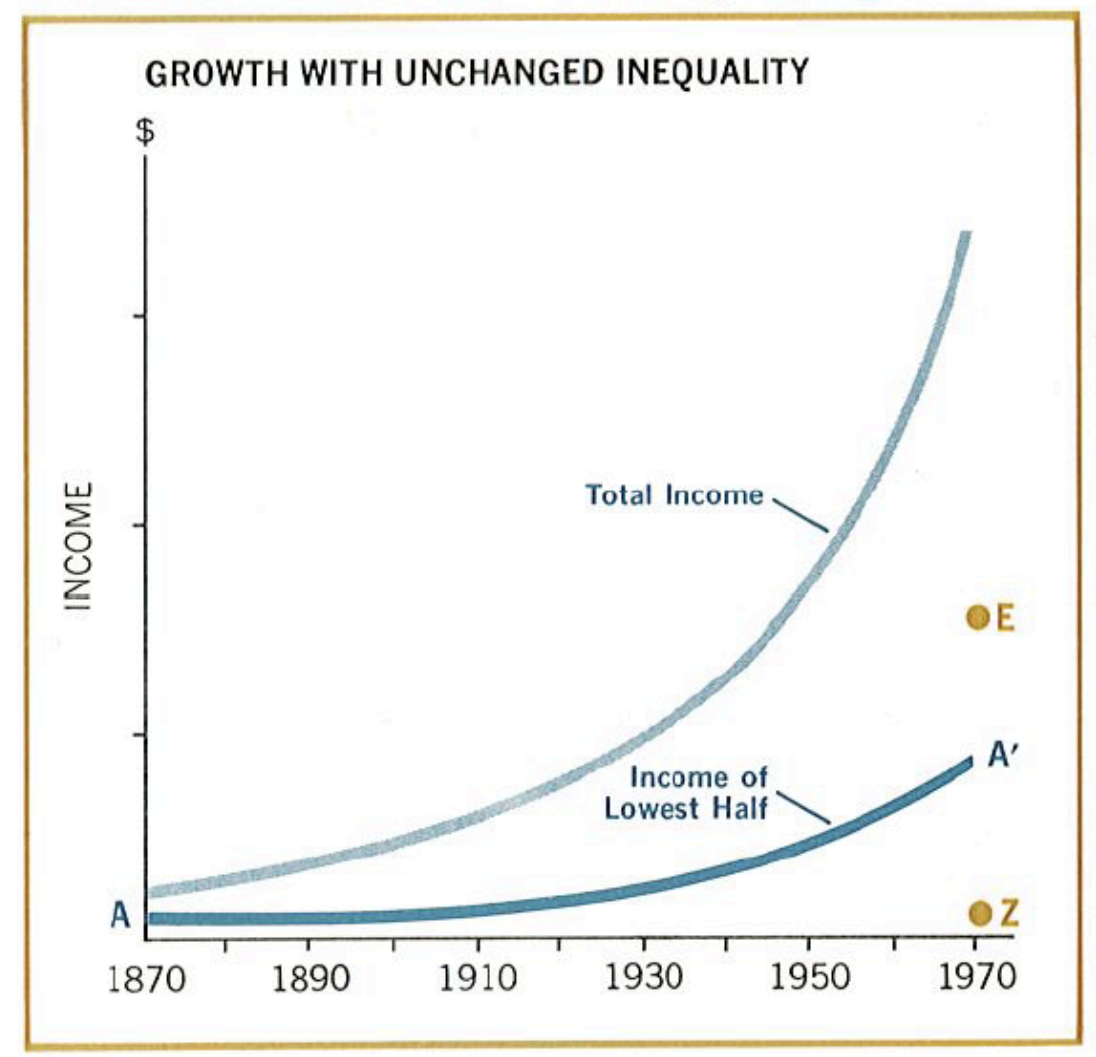

Figure 2. Source: Samuelson's Economics, 8th edition, 1970, 765

In sum, with this edition, Samuelson had tried to handle the radical critique, not by adopting its framework but by applying standard economics treatment to the new issues it addressed. Some of those remained unaddressed, for instance gender discrimination. A number of letters criticizing Samuelson's alleged male-chauvinist prejudices at various points in the textbook had already pointed at this deficiency. Samuelson's assertion that "the girls at Sweet Briar" would not be able to treat some of the most difficult chapter-ending questions, while "honor students at Princeton" would, quoted in the New York Times on the occasion of the release of the latest edition (Shenker 1970, p.41), drew more critical responses. Commercially, the $8^{\text {th }}$ edition represented another disappointment for the author and its editors, as it was the first one to sell fewer copies during its first year than its predecessors despite an important promotion campaign. In addition, some field reports by McGraw-Hill 
travelers suggested that certain institutions were unsatisfied with the textbook and had planned to have it replaced in the near future by a thinner, less sophisticated and less expensive text. To halt the decline in sales, the next edition should go further in addressing topical issues and take radical economics more seriously.

\section{Addressing radical economics, emphasizing the "mainstream": the $9^{\text {th }}$ edition}

While the $8^{\text {th }}$ edition had brought a few novelties in reaction to the issues raised by radical economists, it was not exactly the kind of response that would deter criticism. Samuelson's foray into inequalities and racial discrimination did not convey that mainstream economics had its flaws but served as a demonstration that the basic principles exposed $\mathrm{e}$ in the book could be applied to a large number of social problems. In the radical economist's mind, it was another instantiation of the patronizing tone that Economics adopted, showing to the younger generation that the tools of their predecessors alone would handle their problems. What was not addressed was the radicals' argument that issues over class struggles and capitalist exploitation could not be treated within the framework of standard economics. These are the issues that $9^{\text {th }}$ edition aimed at covering more explicitly.

Here again, the organization provided by McGraw-Hill was helpful. In order to get a more precise understanding of the radical audience's attempts, Samuelson and his editor Michael Elia decided to increase the communication with dissenting instructors. It resulted in their insistence to collect feedback from radical economists, though this segment represented only 5 percent of the profession according to a Wall Street Journal study. ${ }^{21}$ As it happened, only a handful of those were inclined to offer their views on the textbook and therefore

\footnotetext{
${ }^{21}$ Elia to Samuelson, July 15, 1971, Box 80, Folder "Economics, sale reports".
} 
participate in its improvement. Since the publication of the $8^{\text {th }}$ edition, Samuelson had adopted a more explicit skeptical stance against radical economics, most notoriously in hos preface of Assar Lindbeck's 1971 The Economics of the New Left. Subtitled “An Outsider's View" - its author was both Swedish and an orthodox economist -, this short book offered a critical overview of the radical critique, the latter being not exactly the views expressed by professional economists but rather the more general criticisms of Western societies expressed by radical intellectuals of the period. Lindbeck did not mention Bowles or Gintis but rather the older generation of left-wing economists such as Sweezy and Galbraith, as well as Herbert Marcuse, who was referred to as the main intellectual figure of the movement and subsequently discussed at length. Doing so surely undermined younger radicals whose ideas on economics were seen as merely reviving the past. In his foreword, Samuelson made it clear that what the book discussed were the views associated with political activists such as Ralph Nader rather than those of professional radical economists. As often, Samuelson's comments were two-edged, especially when he dealt with the textbook literature: "I may add that some unconventional economic textbooks, written by those proud to call themselves radical economists, are now on the way. This Lindbeck book will not lose in usefulness in being assigned as collateral reading along with such new textbooks (Samuelson in Lindbeck 1971, xiv)."

It is therefore unsurprising that some of the radical instructors that McGraw-Hill approached, especially those in the process of writing competing texts, simply refused to review Economics. For instance, James Weaver, a Professor at the American University in Washington DC, responded that reviewing the book was an impossible task because "[w]ithin the paradigm in which Professor Samuelson [was] working”, it was excellent. But, to this instructor, Economics was "essentially engineering" and "as an attempt to explain human 
behavior, it [was] a complete failure". Then, he added: "If one wishes to restructure society in order to achieve other values than maximizing output of material goods and services, Samuelson's book is no help at all". ${ }^{22}$ The critical comments provided by Richard Roehl, an Assistant Professor at the University of California at Berkeley were characteristic of the radical views. The latter characterized Chapter 5, dealing with incomes and living standards as "a major intellectual obfuscation"; he described Chapter 7, which dealt with labor economics as "wrong", "inadequate" and "myopic, biased, apologetic"; concerning the micro section, on the other hand, he argued that "much of neoclassical theory" was "unobjectionable to radicals"; he complained that chapter 29 , devoted to wage determination, ignored "power relationships". Unsurprisingly, the theory of capital and profit determination was severely criticized. Turning to Part 6 - current economic problems -, the author was almost entirely dismissive, found much material there "pointless", argued that it "fail[ed] to address the basic economic problems" and concluded that it was the "best example of what was wrong with the book". Some of these criticisms echoed those made by more conventional economists, who argued that the final section of the textbook appeared as a "potpourri" and that some of these materials should be dropped altogether and incorporated into other chapters. It was coherent with the general idea that the textbook had become too long. ${ }^{23}$ Another reviewer noted that "for an author who claims to apply the criterion of relevance to all his revisions", Samuelson had "only 2 pages on urban blight and 2 on pollution." 24

The revisions undertaken for the $9^{\text {th }}$ edition reflected these remarks and criticisms. The chapters on environmental problems and discrimination were extended, referring in the first to

\footnotetext{
22 Weaver to Elia, September 10, 1971, PASP, Box 82, Folder "Elia Review of Economics." On this, Samuelson's editor commented that: "If economics is the dismal science, then from this speech, it appears to me that radical economics is a depressing art (Elia to Samuelson, September 14, 1971, ibid.).”

${ }^{23}$ Elia to Samuelson, January 6, 1972, PASP, Box 82, Folder "Elia review of economics."

${ }^{24}$ Elia to Samuelson, February 16, 1972, PASP, Box 82, Folder "Elia review of economics."
} 
the recent criticism of economic growth - the term "ecology" appeared in the chapter title and in the index - and discussing sex discrimination in the second. Yet the most important change made in the $9^{\text {th }}$ edition was a more frontal acknowledgement of the critique of mainstream economics. In the introduction, Samuelson wrote:

It is a scandal that, until recently, even majors in economics were taught nothing of Karl Marx except that he was an unsound fellow. This was not out of intimidation by the plutocratic interests, but rather reflection that such independent and impassioned teachers of the last generation as John Maynard Keynes thought Marx sterile and dull. In this edition I have tried to treat Karl Marx as neither God nor Devil - but as a secular scholar whom half the world's population deem important. The rudiments of mature Marxism, as well as the insights of the resurrected Young Marx, are newly discussed in this revision. ${ }^{25}$

This resulted in a new chapter "Winds of Change: Evolution of Economic Doctrines" (Chapter 42), which included a two-page treatment of radical economics. ${ }^{26}$ This section consisted mostly in reproducing excerpts of a text that was deemed typical of radical economics: a critical piece written by Marxist economist John Gurley on the occasion of the 1970 American Economic Association and subsequently reproduced in the American Economic Review (Gurley 1971). Yet Gurley's critique was counterbalanced by Solow's response in the same issue, which had some of the most brutal rebuttal of radical economics

\footnotetext{
${ }^{25}$ Samuelson 1973, ix.

${ }^{26}$ It is interesting to compare Samuelson's $9^{\text {th }}$ edition with McConnell's $5^{\text {th }}$ edition of 1972 . McConnell addressed topical issues such as racial discrimination, "social imbalance" and labor unions, but at no point he evoked the New Left, which was absent in the index. McConnell's positioning as a more policy-oriented text as well as the author's lesser identification with the mainstream may have spared him the need to undertake such doctrinal exploration, which was unique to Samuelson.
} 
by a standard economist (see above, section 3), and which was quoted in the textbook just after Gurley's comments. Samuelson concluded: “the radical economists are now still doing the research on which they would have the future judge them (p. 851)." He mentioned the Lindbeck book, reiterating his remark made previously in its preface that it was a survey of "the noneconomist New Left". Then, he argued that "[t]he difference between the Old Left and the New Left should not be exaggerated." These remarks were followed by a three-page study of Marxism, supplemented by an eight-page mathematical analysis of "Marxian Economics", the conclusion of which stated that "Marxism may be too valuable to leave to the Marxists. It provides a critical prism through which mainstream economists can - to their own benefit - pass their analyses for audit (p. 866).”

In fact, as the preceding quote indicates, chapter 42 emphasized not so much radical and Marxian economics but its counterpart: "mainstream economics." Though never used in past editions of the textbook, it made its appearance prominently there, as the title of a section. Samuelson wrote: "The whole of this book has been devoted to modern postKeynesian political economy - the mainstream economics that prevails in America and Scandinavia, in England and Holland; and that is coming to prevail increasingly in Japan, France, Italy, and most of the Western world. The fruits of post-Keynesian economics have been the better working of the mixed economy (p. 845)." "Mainstream", here, appeared as relatively vague, differing from today's acceptation of the term. It was not just a theoretical doctrine or a seemingly homogeneous body of knowledge, but more largely a form of government using the historically-loaded "political economy" made it even more ambiguous. In truth, "mainstream" was not so much defined positively by what it was than negatively through the critics, either the "conservative counterattacks against mainstream economics" articulated by "Chicago School Libertarian[s]" (p. 847) about whom very little was said or the 
radicals to whom the remaining part of the chapter was devoted. ${ }^{27}$ Another interesting use of "mainstream" was found in the "family tree of economics" located in the inner cover of the book. A fixture from the $4^{\text {th }}$ edition onward, the family tree changed between the $8^{\text {th }}$ and the 9the edition, as to feature "Post-Keynes Mainstream Economics" in lieu of the "New Economics" of earlier editions (see fig. 3 below).

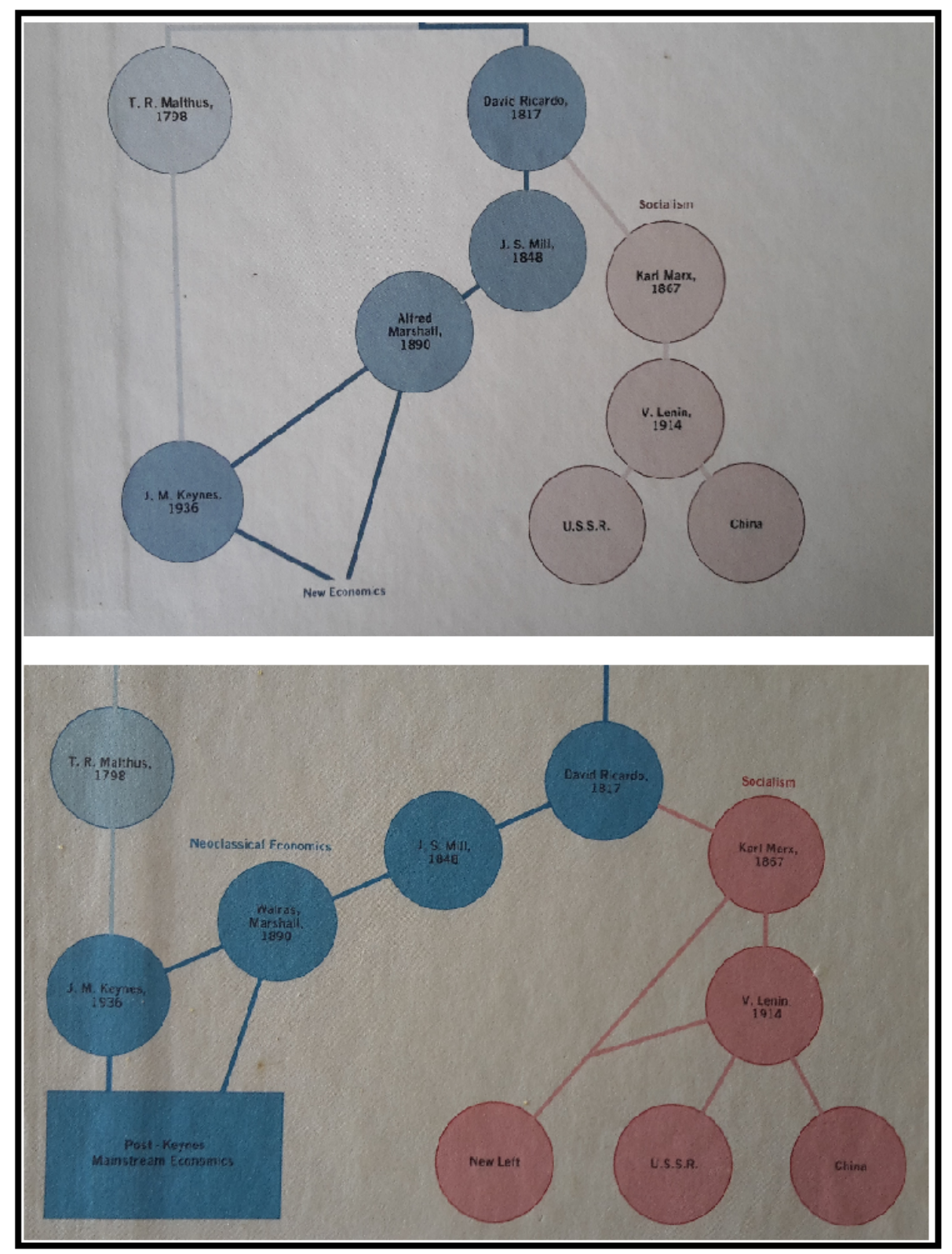

Figure 3. The Family Tree of Economics - 8th edition (top) and 9th edition (down).

\footnotetext{
${ }^{27}$ Samuelson's relative neglect of the Chicago School in the textbook, in contrast to his insistence on addressing Marx and the Radicals, would deserve a separate paper.
} 
Here, "mainstream economics" appeared as the synthesis between Keynesian and Neoclassical economics, its rectangular form standing in contrast to the circles of past economic doctrines. On the other side, the added "New Left" synthesized the views of Marx and Lenin, appearing as a quasi-political force along with China and the USSR. Mainstream economics, therefore, could be seen as the bulwark of 'economic science' against more ideological views of the economy. ${ }^{28}$ In this perspective, Samuelson's vague use of "mainstream" could be seen as a reactivation of his "middle-of-the-road" view that good economics must stay away from extreme policy positions, an argument he had mobilized against conservative critics in the past. $^{29}$

All in all, there was little here to dissipate the radicals' criticisms of Economics and much to attract new ones, as illustrated in Howard Sherman's review of the $9^{\text {th }}$ edition in the September 1973 issue of Challenge. First, Sherman mocked what he considered a deceitful display of open-mindedness on Samuelson's part, calling the book "RRRRRadical" as it contained "every radical issue that [was] now fashionable at cocktail parties". To Sherman, the emphasis on new issues such as ecology and racial discrimination were mainly cosmetic and "in reality, however, Samuelson remain[ed] an apologist for the status quo, taking a cautiously liberal position on every issue - in favor of reforms but no drastic changes." Samuelson's style was questioned throughout the review. In the author's mind, it testified to his talking down to students and his overlooking Marxist analysis, which was treated more technically than most of the other sections in the text. On this, Sherman stated: "The curious question is why Samuelson has to bury his main exposition of Marx in an avalanche of

\footnotetext{
${ }^{28}$ Backhouse 2016 also notes this change in the "family tree" and Cherrier 2016, building on Backhouse's note and using quantitative data from JStor, speculates that these trees may have "exerted an influence on economists' identification and definition of a 'mainstream'." Our paper does not help ground this claim but at least depicts the contest in which Samuelson's utilized the word.

${ }^{29}$ See Giraud 2014.
} 
mathematics. After all, this is a book for elementary students, and all of Marx's Capital was written in a straightforward literary manner with very few mathematical equations (Peterson, Sherman and McCloskey, 1973, pp. 63-5)." Also, the irony of treating the radicals' view through Lindbeck's attack was not lost on the reviewer. In some way, Sherman seemed to prefer Alchian and Allen's version of economics - as presented in their textbook Exchange and Production -, which at least provided a straightforward reactionary position. It was Sherman's idea that the existing conflicting views were underwritten by incommensurable societal conceptions that left no place for a balanced, "middle-of-the-road" point of view. His opinion was representative of the Radical economists' critique, which was directed at liberals rather than conservatives.

Another aspect of the radicals' reaction to the latest editions of Economics was their rejection of the commercial nature of the textbook. This was made explicit in Marc Linder's Anti-Samuelson, a systematic, two-volume long critique of Economics whose American version was published in $1977 .{ }^{30}$ As the author wrote in the introduction: "The inclusion in S's textbook of such diverse topics as pollution racial discrimination, and the militaryindustrial complex was essentially a commercial response to the growing awareness, designed to consolidate S's position in the lucrative textbook market (Linder 1977, vol. 1, vi)". In addition to the bourgeois theory it vilified, Anti-Samuelson was a critique of the practice of textbook making, which was so embedded in the market process radical economists were criticizing. In an endnote, Linder emphasized the commercial aspects, quoting from a 1973

\footnotetext{
${ }^{30}$ Though it only appeared in the United Stated in 1977, three years after the publication of a German fourvolume edition, Anti-Samuelson had been initiated as early as 1970 during the heydays of the radical movement on US campuses. At the time, Linder was a graduate student in philosophy at Princeton University, writing a $\mathrm{PhD}$ dissertation entitled "Reification and the Consciousness of the Critics of Political Economy: Studies in the Development of Marx' Theory of Value". However, he did not get a permanent position before 1983 after he obtained a doctorate in law at Harvard.
} 
article in Business Week - a magazine that was, they insisted, "published by the same corporation (McGraw-Hill) which published the textbook" - that the textbook was "the central feature of a marketing package" that had become "a necessity in an increasingly competitive market". The authors also noted that "in 1970 the value of shipments of the printing and publishing industry amounted to more than \$25 billion" and that "McGraw-Hill itself was the $292^{\text {nd }}$ largest industrial corporation in the U.S. in 1972 with sales of about $\$ 430$ million and profits of approximately \$22.5 million (ibid, vol. 1, 367-8).” Implicit in their view was the idea that a textbook obeying the laws of an increasingly competitive market and dominated by large corporations should be unable to deal with the social concerns radical economists were interested in denouncing. The radicals' repugnance to deal with this mainstream textbook market made Samuelson's attempts to address their criticisms a quite dull initiative.

\section{Conclusion: the death of the textbook author}

Let us go back to Samuelson's fatigue of March 1975 and to what happened next. Following Samuelson's initial letter of resignation to Aksen, a meeting was arranged with the latter ten days later, where it was decided that Samuelson would barely revise the text but would be helped by his colleague at MIT, Peter Temin, who would undertake a statistical revision of the ninth edition, check proofs and incorporate the few changes that were specific to the new edition. Temin was a clever choice, and not just because of his credentials as an economic historian. In 1974, the latter had supervised the revision of the introductory courses of economics at MIT, a class that was still taught to economics students and engineers alike. His revisions, exposed in a memorandum, consisted in making the course more problem-oriented and in expanding the materials used in the class to non-academic texts such as newspapers 
and professional magazines articles. ${ }^{31}$ With Temin onboard, Samuelson would only serve as a consultant and would be little involved in this new volume. Aksen even mentioned that McGraw-Hill could eventually buy him the rights out of his text. While the $11^{\text {th }}$ edition (1979) would return to the single-author mode, subsequent editions would be co-signed by William Nordhaus, with Samuelson lending not much beyond his name to the collaboration. ${ }^{32}$ By that time, then, Economics had fully developed into a commercial franchise. Ironically, it was another step in the process of commercialization of economic education, which the radicals had tried to oppose.

Moral and ideological considerations aside, the story of Samuelson's transformation into a brand bearing his name also illustrates an important feature of the modern textbook: the progressive obliteration of the author. Of course, the anonymous character of science is a normal process as new knowledge becomes universal and subsequently loses its ties to the context in which it was initially produced. That Samuelson, the MIT Professor, became "Samuelson", the household name - Anti-Samuelson, after all, was not a critique of the man but of what was perceived as a cohesive system of thought - only conveys his success in disseminating his views to the point that they would be perceived as those of the economics profession as a whole. Yet, as far as textbooks are concerned, the "death" of the author also points to a different historiographical issue. While previous commenters on Economics have treated the textbook as the sole emanation of Samuelson - as if it were an extended essay like, say, Galbraith's Affluent Society -, our narrative has highlighted the role of the many parties

\footnotetext{
31 Peter Temin, “14.01 and 14.02: Proposed revisions”, Fall 1974, MIT Department of Economics Records, 1947-1982, AC 394, Box 1, Massachusetts Institute of Technology, Institute Archives and Special Collections, Cambridge, Massachusetts.

32 Though there is no direct evidence that Samuelson did not participate in the 'Samuelson and Nordhaus' version of the textbook, the absence of any material related to the revision of Economics after the $11^{\text {th }}$ edition in the archives seems to indicate that his involvement was slight at best.
} 
that are involved in its making: apart from Samuelson himself, this includes his editorial team at McGraw-Hill, not only those providing corrections to the they, but the experts who survey competing texts and hint at possible improvements of the text to enforce market domination; the many instructors who used the textbook in their classes, providing feedback to McGrawHill field reporters; the readers who sent Samuelson unsolicited advices and corrections; the various committees who decided to use the textbook as part of their course materials or to trade it for another better-suited manual; and finally the students whose reaction were sometimes collected. This network, which is not unlike what literary theorist Stanley Fish (1982) has characterized as "interpretive communities", makes it difficult to dissociate what in the revisions of Economics is driven by Samuelson himself from what is driven by the community around him and, more generally, by market forces. Textbooks appear as hybrid objects that embody many different, even conflicting views and interests. Therefore scholars interested in using them to retrace developments in postwar economics should not necessarily assume authorial intent.

\section{References}

Bach, George L. 1954. Economics: an Introduction to Analysis and Policy. New York: Prentice-Hall.

Bach, George L. \& Saunders, Phillip. 1965. "Economic Education: Aspirations and Achievements." American Economic Review, 55 (3): 329-56.

Backhouse, Roger E. 2016. "A short note on the place of mainstream economics in Samuelson's family tree of economics." Working paper, https://papers.ssrn.com/sol3/papers.cfm?abstract id=2783085 (last accessed, July $25^{\text {th }}$, 2017). 
. 2017. Founder of Modern Economics: Paul A. Samuelson. Volume 1: Becoming Samuelson, 1915-1948. Oxford, UK: Oxford University Press.

Bronfenbrenner, Martin. 1970. "Radical Economics in America: a 1970 Survey." Journal of Economic Literature, 8 (3): 747-66.

Cherrier, Béatrice. 2016. "How the term "mainstream economics" became mainstream: a speculation.” Blog entry. https://beatricecherrier.wordpress.com/2016/05/23/how-theterm-mainstream-economics-became-mainstream-a-speculation/ (last accessed, July $\left.24^{\text {th, }} 2017\right)$.

Colander, David, Richard Holt \& Barkley Rosser Jr. 2004. "The changing face of mainstream economics" Review of Political Economy, 16 (4): 485-499.

Davis, John B. 2006. "The turn in economics: neoclassical dominance to mainstream pluralism" Journal of Institutional Economics, 2 (1): 1-20.

De Vroey, Michel and Luca Pensieroso. 2016. "The Rise of a Mainstream in Economics." IRES Discussion Papers. http://hdl.handle.net/2078.1/178096 (last accessed, July 25 ${ }^{\text {th }}$ 2017).

Elzinga, Kenneth G. 1992. "The Eleven Principles of Economics." Southern Economic Journal, 58 (4): 861-79.

Fish, Stanley. 1982. Is There a Text in This Class? The Authority of Interpretive Communities. Cambridge, MA: Harvard University Press.

Fleury, Jean-Baptiste. 2012. “The Evolving Notion of Relevance: An Historical Perspective to the Economics Made Fun Movement.” Journal of economic methodology, 19 (03): 303-19.

Giraud, Yann. 2014. "Negotiating the "Middle-of-the-Road" Position: Paul Samuelson, MIT, and the Politics of Textbook Writing, 1945-55." In MIT and the Transformation of American Economics, edited by E. Roy Weintraub. History of Political Economy 46 (supplement): 134-52. 
Gottesman, Aron A, Ramrattan, Lall \& Szenberg, Michael. 2005. "Samuelson's Economics: The Continuing Legacy." Quarterly Journal of Austrian Economics, 8 (2): 95-104.

Gurley, John G. 1971. "The State of Political Economics.” The American Economic Review, 61 (2): 53-62

Levy, David M. and Sandra J. Peart. 2009. "Soviet Growth and American Textbooks." Working paper, http://ssrn.com/abstract=1517983 (last accessed July 25 ${ }^{\text {th }}, 2017$ ).

Lindbeck, Assar. 1971. The Political Economy of the New Left: An Outsider's View. New York: Harper and Row.

Linder, Marc. 1977. The Anti-Samuelson (two volumes), with the help of Julius Sensat Jr. New York: Urizen Books.

Lipsey, Richard G. 1963. An Introduction to Positive Economics. London, UK : Weidenfield \& Nicolson.

. 1997. "Introduction : An Intellectual Autobiography." In Macroeconomic Theory and Policy: The Selected Essays of Richard G. Lipsey, vol. 2, Cheltenham, UK: Edward Elgar. Lipsey, Richard G. \& Steiner, Peter O. (1966). Economics. New York, NY: Harper \& Row. Mata, Tiago 2009. "Migrations and Boundary Work: Harvard, Radical Economists, and the Committee on Political Discrimination." Science in Context, 22 (1): 115-43.

McConnell, Campbell R. 1960. Economics: Principles, Problems, and Policies. New York: NY: McGraw-Hill. 1972. Economics, $5^{\text {th }}$ ed. New York: McGraw-Hill.

Medema, Steven G. 2014. "How Textbooks Create Knowledge and Meaning: The Case of the Coase Theorem in Intermediate Microeconomics." Working paper, https://papers.ssrn.com/sol3/papers.cfm?abstract id=2479732 $\left(\right.$ last accessed June $29^{\text {th }}$, 2017).

Merton, Robert C. (ed). 1972. The Collected Papers of Paul A. Samuelson, vol. 3. Cambridge, MA: The MIT Press. 
Morgan, Mary S. and Malcolm Rutherford (eds.). 1998. From Interwar Pluralism to Postwar Neoclassicism. Annual supplement to History of Political Economy 40, Durham, NC: Duke University Press.

Nelson, Robert H. 2001. Economics as Religion: from Samuelson to Chicago and Beyond. University Park, PA : The Pennsylvania State University Press.

Pearce, Kerry A. and Hoover, Kevin D. 1995. "After the Revolution: Paul Samuelson and the Textbook Keynesian Model.” In New Perspectives on Keynes;, edited by Allin F. Cottrell. Annual Supplement to History of Political Economy 27 (supplement): 183-216.

Peterson, Wallace C., Sherman, Howard J. \& McCloskey, Donald. 1973. “A Trio of Opinions on the Ninth Edition of Paul Samuelson's Economics." Challenge, 16 (4): 61-6.

Reinhold, Robert. 1970. "Leader of Economic Mainstream: Paul Anthony Samuelson." New York Times, October 27, 1970, p. 8.

Rocke, Alan J. 2010. Images and Reality: Kekule, Kopp and the Scientific Imagination. Chicago, IL: The University of Chicago Press.

Rowen, Hobart. 1969. "Bankers Cheer Defender of Dissident Youth.” The Washington Post, November 18, 1969, p. A4.

Samuelson, Paul A. 1948. Economics: an introductory analysis. New York, NY: McGrawHill. 1955. Economics, 3r ed. New York: McGraw-Hill. 1961. Economics, $5^{\text {th }}$ ed. New York: McGraw-Hill. 1964. Economics, $6^{\text {th }}$ ed. New York: McGraw-Hill. 1967. Economics, $7^{\text {th }}$ ed. New York: McGraw-Hill. 1970. Economics, $8^{\text {th }}$ ed. New York: McGraw-Hill. 1973a. Economics, $9^{\text {th }}$ ed. New York: McGraw-Hill. 
(1997). "Credo of a Lucky Textbook Author.” Journal of Economic Perspectives, 11:

$153-60$.

Samuelson, Paul A. \& Temin, Peter (1976). Economics, $10^{\text {th }}$ ed. New York: McGraw-Hill.

Saunders, Phillip \& Bach, George Leland. 1970. “The Lasting Effects if an Introductory Economics Course: An Exploratory Study." The Journal of Economic Education, 1 (2): $143-9$.

Shenker, Israel. 1970. “Economics, $8^{\text {th }}$ edition”. New York Times, February 5, 1970, p. 41.

Skousen, Mark 1997. “The Perseverance of Paul Samuelson's Economics." Journal of Economic Perspectives, 11 (2): 137-52.

Solow, Robert M., Robert L. Heilbroner and Henry W. Riecken. 1971. "Discussion." The American Economic Review, 61 (2): 63-68.

Vicedo, Marga (2012). “Introduction: The Secret Lives of Textbooks.” Isis, 103 (1): 83-87. 